\title{
PENERAPAN HUKUM RESPONSIF MENJADIKAN KEJAKSAAN YANG PROFESIONAL DALAM PENEGAKAN HUKUM
}

\author{
Oleh: \\ I Putu Gede Darmawan Hadi $\mathbf{S}^{1}$
}

\begin{abstract}
Currently, the policy made by the government will always support the political interests of the government itself, regardless of the interests of the community. A good policy is a policy that can respond and meet the interests, aspirations and social needs of the community so that all aspects must work together. In addition, government policy is expected to prevent violations of the law, because efforts to prevent violations of the law is better than crack or Hank dropped punishment to the offender. By building a national integrity system in government institutions is very useful for the fight against corruption in various forms at various levels. Attorney as law enforcement also plays a role in combating corruption should respond actively so that the desires of society so that the level of corruption in Indonesia decreased can be realized. Criminal punishment to the perpetrators of corruption is a form of repressive law enforcement response, the law does not consider the interests of those who governed / regulated by these laws. This study uses the method of normative legal research, which aims to identify and understand more deeply about the role of the Prosecutor in preventing corruption as well as people's expectations and understanding of the policies applied to the Prosecutor to support the government in preventing corruption.
\end{abstract}

Keywords: Aplication of the Law, Prosecutor, Law Enforcement.

\begin{abstract}
Abstrak
Saat ini, kebijakan yang dibuat pemerintah akan selalu mendukung kepentingan politik pemerintah itu sendiri, terlepas dari kepentingan masyarakat. Kebijakan yang baik adalah kebijakan yang dapat merespon dan memenuhi kepentingan, aspirasi dan kebutuhan sosial masyarakat sehingga segala aspek harus bekerja sama secara bersinergi. Selain itu, kebijakan pemerintah diharapkan mampu mencegah terjadinya pelanggaran hukum, karena upaya pencegahan terjadinya pelanggaran hukum lebih baik dari pada menindak atau mejatuhkan hukuman bagi si pelanggar. Dengan membangun sistem integritas nasional pada lembagalembaga pemerintahan sangat berguna untuk upaya melawan korupsi dalam berbagai bentuk di berbagai tingkatan. Jaksa selaku penegak hukum yang juga berperan dalam memberantas tindak pidana korupsi haruslah merespon secara aktif sehingga keinginan masyarakat supaya tingkat korupsi di Indonesia menurun dapat terwujud. Penjatuhan pidana kepada pelaku-pelaku korupsi merupakan salah satu bentuk respon penegakan hukum secara represif, yaitu hukum yang tidak memperhatikan kepentingan orang-orang yang diperintah/ diatur oleh hukum tersebut. Penelitian ini menggunakan metoda penelitian
\end{abstract}

1 Jaksa Fungsional pada Kejaksaan Negeri Denpasar, Bali. Email : darmawan.tude@gmail.com 
hukum normatif, yang bertujuan untuk mengetahui dan memahami lebih mendalam tentang peran Kejaksaan dalam mencegah terjadinya korupsi sebagaimana harapan masyarakat dan memahami tentang kebijakan-kebijakan yang diterapkan Kejaksaan untuk mendukung pemerintah dalam mencegah korupsi.

Kata kunci: Penerapan Hukum, Kejaksaan, Penegakan Hukum.

\section{PENDAHULUAN}

Perkembangan penegakan hukum yang semakin kompleks seiring dan sejalan dengan keinginan masyarakat yang berharap hukum dapat ditegakkan dengan adil. Penegakan hukum tidak hanya sebatas menjatuhkan pidana kepada pelaku tindak pidana namun penegakan hukum juga dapat ditinjau dari sisi pencegahan untuk dapat mencegah terjadinya suatu tindak pidana. Konsep pemidanaan seiring dengan waktu semakin berkembang mengikuti perkembangan masyarakatnya. Menurut Prof. Harkristuti Harkrisnowo bahwa pemikiran yang berkembang mengenai teori pemidanaan dimulai oleh aliran retributif yang menekankan pada pentingnya pidana sebagai rational reaction pada kejahatan, tanpa perlu mengurai tujuannya lebih lanjut. Kemudian muncul pemikiran deterrence, yang menekankan pidana sebagai upaya untuk mencegah terjadinya kembali (recurrence) kejahatan, baik yang bersifat khusus (bagi pelaku) maupun umum (bagi masyarakat), selanjutnya, meminjam konsep dunia medis, aliran rehabilitatif memandang pidana sebagai 'obat' bagi 'orang yang sakit' (pelaku kejahatan) dengan memperbaiki dan melakukan resosialisasi. $^{2}$

Seluruh konsep pemidanaan tersebut diatas adalah upaya penegakan hukum setelah terjadinya tindak pidana. Di sisi lain, upaya penegakan hukum tidak hanya dapat dilakukan setelah tindak pidana terjadi akan tetapi dapat dilakukan sebelum tindak pidana tersebut terjadi. Sejalan dengan pandangan di bidang kesehatan "lebih baik mencegah penyakit daripada mengobatinya", demikian juga halnya dalam penanganan kasus korupsi dimana lebih baik mencegah timbulnya perbuatan korupsi daripada menindaknya. ${ }^{3}$ Dengan adanya upaya pencegahan/preventif maka menurut penulis akan mengurangi kesempatan untuk melakukan pelanggaran, yang berimbas dapat menekan seminimal mungkin terjadinya tindak pidana korupsi.

2 Harkristuti Harkrisnowo, "Rekonstruksi Konsep Pemidanaan : Suatu Gugatan Terhadap Proses Legislasi dan Pemidanaan di Indonesia," Orasi Pada Upacara Pengukuhan Guru Besar Tetap dalam Ilmu Hukum Pidana Fakultas Hukum Universitas Indonesia di Balai Sidang Universitas Indonesia, Depok, 08 Maret 2003, hlm. 11

3 Monang Siahaan, 2013, Korupsi Penyakit Sosial Yang Mematikan, Cetakan Pertama, PT. Elex Media Komputindo Kelompok Gramedia, Jakarta, hlm. 318. 
Dalam usaha memberantas korupsi sebaiknya ditempuh dua jalur, yaitu jalur preventif dan jalur represif. ${ }^{4}$ Dalam tindak pidana korupsi upaya preventif /pencegahan dewasa ini sangat sedikit di lirik oleh masyarakat (umumnya media masa) karena yang selama ini dilihat adalah upaya represif/ penindakan / penerapan sanksi pidana terhadap pelaku tindak pidana korupsi. Upaya preventif/pencegahan seakanakan merupakan sisi yang tidak penting, dimana sebenarnya upaya preventif/pencegahan adalah upaya awal untuk mencegah terjadinya tindak pidana korupsi. Upaya awal ini tidak hanya dalam bentuk penerangan atau penyuluhan hukum tentang pemberantasan tindak pidana korupsi semata, melainkan sebuah upaya preventif/pencegahan dengan cara masuk kedalam sistem pengelolaan keuangan negara dalam hal ini APBN/ APBD. Terkait pengelolaan APBN/ APBD contoh yang paling sederhana yaitu terkait pelaksanaan pengadaan barang atau jasa pemerintah guna mendukung pembangunan di setiap sektor.

Kejaksaan yang merupakan salah satu Lembaga yang bertugas menegakkan hukum, harus bisa memahami hukum yang semakin berkembang mengikuti perkembangan masyarakat. Untuk merespon hal tersebut Kejaksaan harus mampu memposisikan diri, serta mampu mengambil sebuah kebijakan yang

4 Andi Hamzah, 1984, Korupsi di Indonesia Masalah dan Pemecahannya, PT. Gramedia, Jakarta, hlm. 146. bersifat responsif guna mendukung upaya preventif/pencegahan terjadinya tindak pidana korupsi.

Berangkat dari latar belakang di atas, dalam penelitian ini dapat ditentukan rumusan masalah sebagai berikut:

1. Bagaimanakah Kejaksaan secara profesional dapat berperan aktif mencegah terjadinya korupsi sebagaimana harapan masyarakat?

2. Kebijakan apakah yang telah diterapkan Kejaksaan untuk mendukung pemerintah dalam mencegah korupsi?

Penelitian ini merupakan karya ilmiah asli yang belum pernah diteliti sebelumnya. Adapun karya ilmiah yang terkait dengan karya ilmiah Penulis tentang Penerapan Hukum Responsif Menjadikan Kejaksaan Yang Profesional Dalam Penegakan Hukum yaitu karya ilmiah dari Putu Indrawan Ariadi, tahun 2015 dengan judul Kewenangan Komisi Kejaksaan Terhadap Tugasnya Untuk Melakukan Pengawasan Khususnya Kepada Kewenangan Penuntut Umum yang rumusan masalahnya adalah; 1. Bagaimanakah sistem kerja komisi kejaksaan untuk melakukan pengawasan terhadap penuntut umum?; 2. Kendala apa sajakah yang didapat komisi kejaksaan terhadap fungsinya melakukan pengawasan terhadap penuntut umum $?^{5}$. Karya

5 Indrawan Ariadi, Putu. KEWENANGAN KOMISI KEJAKSAAN TERHADAP TUGASNYA UNTUK MELAKUKAN PENGAWASAN KHUSUSNYA 
ilmiah lainnya yang terkait yaitu I Putu Carlos Dolesgit tahun 2013 dengan judul Tugas Dan Kewenangan Polresta Denpasar Dalam Penegakan Hukum Dan Penanggulangan Pelanggaran Karya Cipta Lagu Di Kota Denpasar yang rumusan masalahnya adalah; 1 . Bagaimanakah mekanisme Polresta Denpasar dalam menanggulangi pelanggaran hak cipta lagu di Kota Denpasar?; 2. Faktor apa yang mempengaruhi Polresta Denpasar dalam menanggulangi pelanggaran hak cipta lagu di Kota Denpasar? ${ }^{6}$. Jelas nampak perbedaan dari karya ilmiah tersebut dengan karya ilmiah yang dibuat oleh Penulis. Adapun keunggulan karya ilmiah ini dari karya ilmiah lainnya yaitu membahas lebih khusus mengenai peran dan kebijakankebijakan yang diterapkan Kejaksaan dalam mencegah terjadinya korupsi sebagaimana harapan masyarakat.

KEPADA KEWENANGAN PENUNTUT UMUM. Jurnal Magister Hukum Udayana (Udayana Master Law Journal), vol. 4 no. 4 edisi desember 2015 . <https:// ojs.unud.ac.id/index.php/jmhu/article/ view/18741 $>$ Date accessed: 10 Pebruari $2017 . \quad$ doi: $<$ https://doi.org/10.24843/ JMHU.2015.v04.i04.p03.

6 Dolesgit, I Putu Carlos. TUGAS DAN KEWENANGAN POLRESTA DENPASAR DALAM PENEGAKAN HUKUM DAN PENANGGULANGAN PELANGGARAN KARYA CIPTA LAGU DI KOTA DENPASAR. Jurnal Magister Hukum Udayana (Udayana Master Law Journal), vol. 2 no. 2 edisi juli 2013. <https://ojs.unud.ac.id/index. php/jmhu/article/view/5932>.Diakses tanggal 10 pebruari 2017. doi: <https:// doi.org/10.24843/JMHU.2013.v02.i02. p01.
Tujuan dari penelitian ini adalah untuk mengetahui lebih mendalam tentang peran Kejaksaan dalam mencegah terjadinya korupsi sebagaimana harapan masyarakat dan memahami tentang kebijakankebijakan yang diterapkan Kejaksaan untuk mendukung pemerintah dalam mencegah korupsi.

\section{METODE PENELITIAN}

Penelitian hukum merupakan segala aktivitas seseorang untuk menjawab permasalahan hukum yang bersifat akademik dan praktis, baik yang bersifat asas-asas hukum, norma-norma hukum yang hidup dan berkembang dalam masyarakat yang berkenaan dengan kenyataan hukum dan masyarakat ${ }^{7}$. Penulisan karya ilmiah ini menggunakan jenis penelitian hukum normatif. Menurut pandangan Abdulkadir Muhammad dalam bukunya yang berjudul "Hukum dan Penelitian Hukum”, menyatakan bahwa $^{8}$ :

"Penelitian hukum normatif adalah penelitian hukum yang mengkaji hukum tertulis dari berbagai aspek yaitu aspek teori, sejarah, filosofi, perbandingan, struktur dan komposisi, lingkup dan materi konsistensi, penjelasan umum dan pasal demi pasal, formalitas dan kekuatan mengikat suatu undang-undang, serta bahasa hukum yang dipergunakan".

7 Zainuddin Ali, 2009, Metode Penelitian Hukum, Sinar Grafika, Jakarta, hlm.19 Abdulkadir Muhammad, 2004, Hukum dan Penelitian Hukum, PT Citra Aditya Bakti, Bandung, hlm. 101 
Penelitian hukum normatif dilakukan dengan cara meneliti bahan hukum yang diperoleh dari bahan hukum primer, bahan hukum sekunder dan bahan hukum tersier, serta dalam penelitian hukum ini mempergunakan pendekatan dalam memecahkan masalah, yaitu dengan menggunakan pendekatan perundangundangan (the statute approach) yang berhubungan dengan masalah yang dibahas ${ }^{9}$. Metode yang digunakan dalam melakukan penelitian ini adalah metode pendekatan yuridis normatif yang menitik beratkan pada penelitian bahan pustaka atau data sekunder belaka yang menitik beratkan pada bahan-bahan kepustakaan, ${ }^{10}$ sehingga dapat memberikan gambaran mengenai fakta disertai dengan analisis dalam penerapan Hukum Responsif oleh Penegak Hukum khususnya Kejaksaan.

\section{HASIL DAN PEMBAHASAN}

3.1 Peran Aktif Kejaksaan Dalam Mencegah Korupsi

Pemahaman tentang pemberantasan korupsi hanya sebatas penjatuhan pidana tentu merupakan pemikiran yang tidak bersifat Progresif. Sebagaimana pendapat Yudi Kristania yang mengutip dari gagasan Satjipto Rahardjo tentang "Identifikasi Hukum

9 Peter Mahmud Marzuki, 2011, Penelitian Hukum, Kencana Prenada Media Group, Jakarta, hlm. 93

10 Soerjono Soekanto dan Sri Mamudji, 2004, Penelitian Hukum Normatif Suatu Tinjauan Singkat, Cetakan kedelapan, PT. RajaGrafindo Persada, Jakarta, hlm. 13-14.
Progresif' menyebutkan salah satu karakter hukum progresif adalah secara sadar menempatkan kehadirannya dalam hubungan erat dengan manusia dan masyarakat, meminjam istilah Nonet \& Selznick bertipe Responsif. ${ }^{11}$ Secara historis teori hukum responsif merupakan tujuan utama penganut realism hukum (legal realism) dan Sociological Jurisprudence. ${ }^{12}$ Teori hukum ini menginginkan hukum lebih responsif terhadap kebutuhan sosial masyarakat sehingga segala aspek harus bekerja sama secara bersinergi.

Terkait dengan pemberantasan korupsi di Indonesia, perlu sinergisitas dari setiap instansi-instansi pemerintah yang terkait dengan pengelolaan keuangan Negara, guna tercapainya tujuan pembangunan. Kejaksaan sendiri dipandang belum maksimal dalammenanganitindakpidanakorupsi yang disebabkan oleh beberapa faktor dimana salah satunya adalah hubungan lembaga baik secara internal maupun eksternal yang belum terkoordinasi dengan baik. ${ }^{13}$

11 Aliyth Prakarsa, 2010, Re-Reformasi Kejaksaan Sebagai Upaya Pengembalian Kepercayaan Masyarakat Yang Mendambakan Penegakan Hukum, dalam Komisi Hukum Nasional, "Probematika Penegakan Hukum Kajian Reformasi Lembaga Penegakan Hukum”, Cetakan Pertama, KHN RI, Jakarta, hlm. 88-89.

12 Philippe Nonet and Philip Selznick diterjemahkan oleh Huma, 2003, Law and Society in Transision: Toward Responsif Law, Jakarta, hlm. 59.

13 Komisi Hukum Nasional, 2010, "Desain Hukum Indonesia Kado 10 th Komisi Hukum Nasional", Cetakan Pertama, KHN RI, Jakarta, hlm. 32. 
Kejaksaan dalam hal ini Jaksa, selain dituntut professional dalam penanganan perkara di bidang peradilan pidana juga harus mampu bekerja sama dengan lembaga penegak hukum lainnya, ${ }^{14}$ guna tercapainya tujuan pencegahan tindak pidana korupsi. Kerja sama antara Kejaksaan dengan penegak hukum lainnya bukan hanya dengan pihak KPK, Kepolisian dan pihak Pengadilan saja, melainkan dengan semua instansi pemerintahan yang ada di pusat maupun di daerah. Kejaksaan harus mampu bekerja sama dengan instansi pemerintahan dalam hal ini pihak eksekutif yaitu Pemerintah Daerah, karena Pemerintah Daerah adalah ujung tombak pembangunan di daerah yang bersentuhan langsung dengan proyek-proyek pengadaan yang menggunakan APBN dan APBD.

Dari sekian banyak kasus korupsi, sebagian besar terjadi dalam hal pengelolaan APBN/APBD, sehingga modus korupsi yang lazimnya terjadi adalah saat proses persiapan pengadaan seperti tender, perhitungan harga sementara dan lain-lain. Upaya pencegahan yang dilakukan oleh Kejaksaan harusnya mampu masuk kedalam sistem pengelolaan APBN/ APBD, sehingga Kejaksaan dapat berperan aktif guna mengurangi niatniat para pejabat dalam melakukan korupsi. Keaktifan Kejaksaan ini diharapkan mampu mencegah

14 Komisi Hukum Nasional, 2008, "Kebijakan Reformasi Hukum Suatu Rekomendasi 1 \& 2", Cetakan Kedua, KHN RI, Jakarta, hlm. 257 terjadinya tindak pidana korupsi. Sehingga kejaksaan harus membuat sebuah strategi preventif yang diharapkan dapat mencegah terjadinya korupsi dengan cara meminimalkan atau bahkan menghilangkan faktorfaktor / peluang terjadinya korupsi dalam pengelolaan APBN/APBD serta meningkatkan upaya-upaya untuk mendeteksi peluang terjadinya korupsi. ${ }^{15}$ Upaya pendeteksian awal inilah yang menjadi peran utama upaya preventif kejaksaan mencegah korupsi. Sebagaimana pendapat Maswadi Rauf seorang pengamat Politik Universitas indonesia mengatakan Kejaksaan juga berperan dalam memberantas korupsi dimana Kejaksaan kini semakin intensif dalam memberantas korupsi baik di pusat dan daerah. Meningkatnya kinerja Kejaksaan dalam mengungkap kasus-kasus korupsi seperti saat ini menjadi sinyalemen positif. Kekuatan personel yang ada di seluruh wilayah sebaiknya dimanfaatkan dengan maksimal dalam upaya pemberantasan korupsi. ${ }^{16}$

Menurutpenulis, untukmerespon keinginan masyarakat supaya korupsi

15 PetterLangseth, Ph. D, 1999, "Prevention: An Effective Tool to Reduce Corruption", United Nation Office For Drug Control And Crime Prevention (UN-ODCCP), "Global Programme Against Corruption Conforences", Viena, hlm. 24.

16 Okezone, 2015, "Beban KPK Semakin Berat, Kejaksaan Harus Pro Aktif", available from: URL: http://news. okezone.com/read/2015/11/15/337/1249 665/beban-kpk-semakin-berat-kejaksaanharus-pro-aktif, diakses pada tanggal 10 Perbuari 2017. 
berkurang di Indonesia maka upaya pencegahan adalah hal yang lebih penting daripada upaya penindakan. Jikalau Kejaksaan mampu mencegah terjadinya korupsi dengan masuk ke dalam sistem dan terlibat dalam sistem pengelolaan keuangan Negara maka setiap perencanaan penggunaan keuangan Negara akan dapat dikontrol dan dilakukan pemantauan sehingga Pengelolaan APBN/APBD tersebut sesuai dengan aturan hukum dan diharapkan tidak ada penyalahgunaan kewenangan oleh pejabat atau pihak terkait yang mengelola APBN/APBD.

\subsection{Kebijakan Mendukung Korupsi.}

Produk regulatif (Excekutive $A c t s^{17}$ ) atau kebijakan sebuah lembaga merupakan tindakan ke pemerintahan yang tidak membutuhkan persetujuan DPR karena dalam rangka menegakkan ketertiban umum, sehingga kebijakan harus dipandang dari tercapainya suatu tujuan dan kehendak yang ditetapkan oleh suatu kebijakan, yaitu melindungi kepentingan umum. ${ }^{18}$ Presiden Joko Widodo selaku Kepala Pemerintahan telah menerbitkan Instruksi Presiden Nomor 7 Tahun 2015 Tentang Aksi Pencegahan dan

17 Jimly Asshiddiqqie, 2006, Hukum Acara Pengujian Undang-Undang, Konstitusi Press, Jakarta, hlm. 39.

18 Dian Puji N. Simatupang, 2011, Paradoks Rasionalitas Perluasan Ruang Lingkup Keuangan Negara Dan Implikasinya Terhadap Kinerja Keuangan Pemerintah, Badan Penerbit FHUI, Jakarta, hlm. 298-299.
Pemberantasan Korupsi pada tanggal 6 Mei 2015, dimana Kementerian PPN/BAPPENAS menjadi tuan rumah peluncuran Instruksi Presiden (Inpres) Republik Indonesia Nomor 7 Tahun 2015 Tentang Aksi Pencegahan dan Pemberantasan Korupsi Tahun 2015 pada hari Selasa tanggal 26 Mei $2015 .{ }^{19}$ Inpres yang ditujukan kepada Kementerian atau Lembaga serta Pemerintah Daerah itu dimaksudkan untuk memaksimalkan pelayanan kepada masyarakat dan membentengi kebijakan dari tindak pidana korupsi.

Sebagaimana Instruksi Presiden Nomor 7 Tahun 2015 Tentang Aksi Pencegahan dan Pemberantasan Korupsi Tahun 2015 yang bertujuan untuk mencegah terjadinya tindak pidana korupsi pada Instansi Pemerintah $^{20}$ maka Kejaksaan RI dalam hal ini telah menindaklanjuti dengan membentuk Tim Pengawal dan Pengaman Pemerintahan dan Pembangunan (TP4) yang berdasarkan pada Keputusan Jaksa Agung RI Nomor : Kep-152/A/JA/10/2015 Tentang Pembentukan Tim Pengawal dan Pengaman Pemerintahan dan Pembangunan Kejaksaan RI tertanggal 1 Oktober 2015, yang terdiri dari TP4 Pusat (TP4P) berkedudukan di

19 Kementrian PPN/Bapenas, 2015 "Presiden Joko Widodo Terbitkan Instruksi Presiden Nomor 7 Tahun 2015 Tentang Aksi Pencegahan dan Pemberantasan Korupsi”, available from: URL: http://www.bappenas. go.id/id/berita-dan-siaran-pers/presiden-jokowidodo-terbitkan-instruksi-presiden-nomor7-tahun 2105-tentang-aksi-pencegahan-danpemberantasan-korupsi, diakses pada tanggal 10 Pebruari 2017

20 Ibid. 
Kejaksaan Agung RI, TP4 Daerah (TP4D) yang berkedudukan masingmasing di Kejaksaan Tinggi dan Kejaksaan Negeri. Pembentukan TP4P/TP4D merupakan bentuk respon Kejaksaan (dalam upaya preventif/ pencegahan) untuk mengawal pengelolaan APBN/APBD sehingga tepat sasaran. Tim tersebut nantinya bertugas memberikan penerangan dan pendampingan hukum, termasuk bersama-sama melakukan monitoring dan evaluasi pelaksanaan pekerjaan dan program pembangunan sehingga penyerapan anggaran APBN/APBD terlaksana dengan maksimal.

Dalam hal me monitoring dan mengevaluasi pelaksanaan pekerjaan, di sinilah bidang intelijen serta bidang perdata dan tata usaha Negara (Datun) di Kejaksaan berperan utama yang diharapkan menjadi ujung tombak berkurangnya korupsi di Indonesia, dimana kedua bidang ini dapat berkolaborasi melakukan pendekatan preventif dan edukatif selain tindakan represif yang dilakukan bidang Tindak Pidana Khusus (Pidsus) Kejaksaan. Untuk di daerah, TP4D harus berperan aktif melakukan komunikasi dengan Pemerintah Daerah setempat sehingga setiap pengelolaan keuangan nagara (penyerapan anggaran) terkait pembangunan insprastruktur di daerah dapat dipantau guna dapat mencegah bahkan menghilangkan peluang korupsi bagi pejabat di daerah.

Hanya saja Pembentukan TP4D tidak serta merta dapat memaksa Pemerintah Daerah untuk memanfaatkan Tim Bentukan Kejaksaan ini, karena tidak ada keharusan bagi Pemerintah Daerah untuk melibatkan TP4D dalam setiap penggunaan anggaran oleh Satuan Kerja Perangkat Daerah (SKPD). Pemerintah Daerah dapat memanfaatkan TP4D jika SKPD berkeinginan dan dapat juga tidak memanfaatkan TP4D jika mereka merasa tidak perlu. Ketidakwajiban SKPD melibatkan TP4D dalam setiap penggunaan anggaran tentu saja masih membuka peluang korupsi atau dapat mengurangiupaya pencegahan korupsi. Seorang pejabat SKPD yang dari awal ingin atau mempunyai niat korupsi masih mendapatkan kesempatan untuk melakukan korupsi, dalam artian TP4D yang dibentuk masing-masing Kejaksaan Tinggi dan Kejaksaan Negeri berdasarkan Keputusan Jaksa Agung RI Nomor : Kep-152/A /JA/ 10/2015 tanggal 1 Oktober 2015 masih memiliki kelemahan karena bersifat tidak mengikat SKPD / Pemerintah Daerah.

Untuk profesionalitas Kejaksaan dalam mengawal penyerapan anggaran di setiap SKPD, maka Kejaksaan Agung dapat kiranya mengusulkan kepada DPR RI selaku badan legislasi yang mana setiap tugas dan fungsi TP4 tingkat Pusat maupun Daerah dimasukkan menjadi tugas tambahan Jaksa dalam revisi UU Kejaksaan. Dengan masuknya tugas dan fungsi TP4 dalam Perundang- 
undangan maka, tidak ada alasan bagi Pemerintah Daerah untuk tidak melibatkan Kejaksaan dalam setiap monitoring dan evaluasi pelaksanaan pekerjaan dan program pembangunan, sehingga akan menutup peluang SKPD yang mengelola APBN/APBD untuk melakukan penyalahgunaan wewenang guna melakukan korupsi.

Anggota Dewan harusnya dapat merespon dengan cepat dengan adanya TP4P dan TP4D bentukan pemerintahan Joko Widodo. Politik hukum DPR RI harusnya mendukung usaha Presiden untuk menutup kerankeran korupsi dengan mengundangkan atau memasukkan tugas dan fungsi TP4D kedalam peraturan perundangundangan sehingga DPR RI memiliki semangat yang sama dengan keinginan masyarakat Indonesia yaitu memberantas Korupsi di Indonesia. Bentuk respon seperti tersebut diatas diharapkan dimiliki oleh DPR RI yang sesuai dengan semangat Hukum Responsif dengan mengutamakan upaya-upaya preventif (pencegahan).

Dengan memasukkan tugas dan fungsi TP4D kedalam peraturan perundang-undangan maka secara langsung DPR juga membantu mencegah terjadinya korupsi dengan upaya memasukkan peran Jaksa ke dalam sistem pengelolaan keuangan Negara. Dimana Jaksa mempunyai tugas tambahan mengawal Pengelolaan Keuangan Negara dengan melakukan monitoring dan evaluasi pelaksanaan pekerjaan dan program pembangunan di setiap SKPD. Karena produk DPR RI adalah bersifat politis dalam pembentukan peraturan perundangundangan yang belum tentu upaya pencegahan terhadap korupsi di setujui oleh anggota Dewan, ${ }^{21}$ maka menurut penulis upaya preventif lain yang dapat dilakukan oleh presiden adalah melakukan perubahan terhadap Peraturan Presiden RI No. 4 Tahun 2015 tentang Perubahan Keempat Atas Peraturan Presiden Nomor 54 Tahun 2010 Tentang Pengadaan Barang/ Jasa Pemerintah. Perubahan yang penulis maksudkan adalah dengan menambahkan ketentuan dalam pasal 17 Ayat (2) huruf g point 5 dan huruf h point 4, dengan mewajibkan kepada KepalaUnit Layanan Pengadaan(ULP) dan Pejabat Pengadaan untuk membuat laporan berkelanjutan mengenai proses Pengadaan yang ditembuskan juga kepada Kejaksaan di Daerah setempat. Tujuan laporan tembusan tersebut adalah untuk mendukung Instruksi Presiden Nomor 7 Tahun 2015 Tentang Aksi Pencegahan dan Pemberantasan Korupsi Tahun 2015.

Dengan adanya kewajiban setiap SKPD (Kepala ULP dan Pejabat Pengadaan)melaporkan setiaptindakan pengadaan barang / jasa kepada Kejaksaan baik dari tahap perencanaan hingga pelaksanaannya maka secara langsung Kejaksaan dapat memantau proses pengelolaan Keuangan Negara. Sehingga antara TP4D bentukan

21 Moh. Mahfud M.D, 2010, Politik Hukum di Indonesia (Edisi Revisi), PT. Raja Grafindo Persada, Jakarta, hlm. 7. 
Kejaksaan dapat sinergi dengan kewajiban dari SKPD untuk membuat laporan, dalam hal ini kalaupun SKPD tidak menggunakan/ tidak meminta pertimbangan TP4D dalam pengadaan barang/jasa, akan tetapi ada kewajiban mereka melaporkan setiap proses pengadaan barang dan jasa, secara tidak langsung SKPD akan terawasi dan sedikit tidaknya mengurangi niat mereka yang akan korupsi dan secara tidak langsung kejaksaan juga terlibat aktif dalam sistem pengelolaan keuangan nagara oleh SKPD. Dengan masuk kedalam sistem berarti jaksa berperan aktif dalam mencegah terjadinya tindak pidana korupsi, di sini baru penulis melihat kalau peran Jaksa adalah sebagai "Imun Anti Korupsi”.

Upaya preventif Kejaksaan dengan membentuk TP4P dan TP4D tentu tidak lepas dari permasalahan yang timbul kemudian. Salah satu hambatan adalah TP4P dan TP4D adalah Tim bentukan baru yang tidak memiliki anggaran untuk pelaksanaan kegiatanbaikdipusatmaupundidaerah. Sehingga kegiatan TP4 seakan akan menjadi pasif bahkan hanya sekedar simbol upaya pemberantasan korupsi. Selain itu belum adanya Peraturan Pelaksana / SOP yang mendukung kinerja Tim Pengawal dan Pengaman Pemerintahan dan Pembangunan (TP4), sehingga Jaksa yang bertugas dalam TP4 akan ragu-ragu dalam mengambil sebuah kebijakan atau tindakan terkait pendampingan atau pertimbangan hukum yang dilakukan pada saat tahap perencanaan dan pelaksanaan suatu pengadaan. Disisi lain ada ketakutan Jaksa TP4 dalam memberikan pertimbangan dikarenakan kalau setelah diberikan pertimbangan hukum dan nantinya ditemukan indikasi korupsi dalam pengadaan yang disebabkan penyalahgunaan wewenang pihak lain, maka jaksa yang bersangkutan merasa terbebani ikut bertanggung jawab terhadap pengadaan yang ia tangani saat pendampingan dalam memberikan pertimbangan hukum.

Terlepas dari semua hambatan yang ada dihadapi, Kejaksaan menjadi ujung tombak dalam pencegahan terjadinya tindak pidana korupsi. Dengan adanya TP4P dan TP4D diharapkan peran bidang Intelijen Kejaksaan dan peran bidang Perdata dan Tata Usaha Negara (Datun) Kejaksaan menjadi ujung tombak pencegahan korupsi, selain bidang Tindak Pidana Khusus (Pidsus) Kejaksaan yang merupakan ujung tombak upaya penindakan (represif) pemberantasan korupsi. Semua diharapkan dapat bekerja sama secara bersinergi guna mendukung kebijakan pemerintah tentang Aksi Pencegahan dan Pemberantasan Korupsi. Selain itu Kejaksaan juga dituntut lebih professional khusus jaksa-jaksa yang bertugas dalam TP4P dan TP4D diharapkan sangat memahami segala bentuk pengelolaan APBN/APBD dari tahapan perencanaan, pengadaan 
hingga ke tahap serah terima. Jaksajaksa harus mampu memberikan pertimbangan hukum di setiap tahapan pengadaan.

\section{KESIMPULAN}

Berdasarkan yang telah diuraikan sebelumnya, maka dapat ditarik beberapa kesimpulan yaitu :

1. Merespon keinginan masyarakat supaya korupsi berkurang di Indonesia maka upaya pencegahan adalah yang lebih penting dilakukan Kejaksaan daripada upaya penindakan, karena jika Kejaksaan mampu mencegah terjadinya korupsi dengan masuk ke dalam sistem dan terlibat dalam sistem pengelolaan APBN/APBD maka setiap perencanaan Pengelolaan APBN/APBD akan dapat dikontrol dan dilakukan pemantauan, sehingga diharapkan tidak ada penyalahgunaan kewenangan oleh pejabat atau pihak terkait yang mengelola APBN/APBD.

2. Kejaksaan RI telah merespon secara aktifkebijakan pemerintah dalamupayaAksiPencegahandan Pemberantasan Korupsi dengan membentuk Tim Pengawal dan Pengaman Pemerintahan dan Pembangunan (TP4) di tingkat Pusat (TP4P) maupun di Tingkat Daerah (TP4D). Pembentukan Tim Pengawal dan Pengaman Pemerintahan dan Pembangunan (TP4) merupakan bentuk respon Kejaksaan RI (bertujuan preventif/pencegahan) untuk mengawal pengelolaan APBN/ APBD sehingga tepat sasaran.

\section{DAFTAR PUSTAKA}

\section{Buku:}

Ali, Zainuddin, 2009, Metode Penelitian Hukum, Sinar Grafika, Jakarta.

Muhammad, Abdulkadir, 2004, Hukum dan Penelitian Hukum, PT Citra Aditya Bakti, Bandung.

Mahmud Marzuki, Peter, 2011, Penelitian Hukum, Kencana Prenada Media Group, Jakarta.

Arinanto, Satya \& Ninuk Triyanti, 2011, Memahami Hukum Dari KonstruksiSampaiImplementasi, Cetakankedua,PT. RajaGrafindo Persada, Jakarta.

Asshiddiqqie, Jimly, 2006, Hukum Acara Pengujian UndangUndang, Konstitusi Press, Jakarta.

Hamzah, Andi. 1984, Korupsi di Indonesia Masalah dan Pemecahannya, PT. Gramedia, Jakarta.

Mahfud M.D, Moh., 2010, Politik Hukum di Indonesia (Edisi Revisi), PT. Raja Grafindo Persada, Jakarta.

Nonet, Philippe and Philip Selznick diterjemahkan oleh Huma, 2003, Law and Society in Transision: Toward Responsif Law, Jakarta.

Siahaan, Monang, 2013, Korupsi PenyakitSosial Yang Mematikan, 
Cetakan Pertama, PT. Elex

Media Komputindo Kelompok

Gramedia, Jakarta.

Simatupang, Dian Puji N., 2011,

Paradoks

Rasionalitas

Perluasan Ruang Lingkup

Keuangan Negara Dan

Implikasinya Terhadap Kinerja

Keuangan Pemerintah, Badan

Penerbit FHUI, Jakarta.

Soekanto, Soerjono. \& Sri Mamudji, 2004, Penelitian Hukum Normatif Suatu Tinjauan Singkat, Cetakan kedelapan, PT. RajaGrafindo Persada, Jakarta.

\section{Peraturan Perundang-Undangan:}

Instruksi Presiden (Inpres) Republik Indonesia Nomor 7 Tahun 2015

Tentang Aksi Pencegahan dan Pemberantasan Korupsi Tahun 2015 tanggal 6 Mei 2015.

Keputusan Jaksa Agung RI Nomor :

Kep-152/A/JA/10/2015 Tentang

Pembentukan Tim Pengawal dan Pengaman Pemerintahan dan Pembangunan Kejaksaan RI, tanggal 1 Oktober 2015.

Disertasi, dan Data/Sumber Yang Tidak Diterbitkan:

Badan Pengawas Keuangan
dan Pembangunan, 2002,
"Upaya Pencegahan Dan
Penanggulangan Korupsi Pada
Pengelolaan APBN/APBD",
Jakarta,

Harkrisnowo, Harkristuti. 2003,
"Rekonstruksi Konsep

Pemidanaan : Suatu Gugatan

Terhadap Proses Legislasi dan

Pemidanaan di Indonesia", Orasi Pada Upacara Pengukuhan Guru Besar Tetap dalam Ilmu Hukum Pidana Fakultas Hukum Universitas Indonesia di Balai Sidang Universitas Indonesia, Depok.

Kementrian PPN/Bapenas, "Presiden Joko Widodo Terbitkan Instruksi Presiden Nomor 7 Tahun 2015 Tentang Aksi Pencegahan dan Pemberantasan Korupsi”, 27 Mei 2015, availablefrom:URL:http:// www.bappenas.go.id/id/beritadan-siaran-pers/presiden-jokowidodo-terbitkan-instruksipresiden-nomot-7-tahun-2915tentang-aksi-pencegahan-danpemberantasan-korupsi, diakses pada tanggal 10 Pebruari 2017

Komisi Hukum Nasional, 2008, "Kebijakan Reformasi Hukum Suatu Rekomendasi 1 \& 2", Cetakan Kedua, KHN RI, Jakarta. , 2010, "Probematika

Penegakan Hukum Kajian Reformasi Lembaga Penegakan Hukum", Cetakan Pertama, KHN RI, Jakarta. , 2010. "Desain Hukum Indonesia Kado 10 th Komisi Hukum Nasional", Cetakan Pertama, KHN RI, Jakarta. 
Makalah \& Artikel online:

Dolesgit, I Putu Carlos. TUGAS DAN KEWENANGAN POLRESTA DENPASAR DALAM PENEGAKAN HUKUM

DAN PENANGGULANGAN PELANGGARAN KARYA CIPTA LAGU DI KOTA DENPASAR. Jurnal Magister Hukum Udayana (Udayana Master Law Journal), vol. 2 no. 2 edisi juli 2013. <https:// ojs.unud.ac.id/index.php/jmhu/ article/view/5932>. Diakses tanggal 10 pebruari 2017. doi: https://doi.org/10.24843/ JMHU.2013.v02.i02.p01.

Indrawan

Ariadi,

Putu.

$\begin{array}{llllllllll}K & E & W & E & N & A & N & G & A & N\end{array}$ KOMISI KEJAKSAAN

TERHADAP TUGASNYA UNTUK MELAKUKAN P $E$ E $N$ G A W A $S$ A $N$ KHUSUSNYA KEPADA KEWENANGAN PENUNTUT UMUM. Jurnal Magister Hukum Udayana (Udayana Master Law Journal), vol. 4 no. 4 edisi desember 2015. $<$ https://ojs.unud.ac.id/index. $\mathrm{php} / \mathrm{jmhu} /$ article/view/18741>. Date accessed: 10 Pebruari 2017. doi: https://doi.org/10.24843/ JMHU.2015.v04.i04.p03

Jamin, Muhamad dkk, "The Politics of Law Formula ofCustomary Court Recognition which Responds to the Indigenous People's Needs (A Study of the Papua Special Autonomy Act)," Journal of Law,
Policy and Globalization, IISTE Knowledge Sharing Partners, Vol. 19, 2013, hal. 75, available from: URL: http://iiste.org/ Juornal/index.php/JLPG/article/ viewFile/8930/9088, diakses pada tanggal 10 Pebruari 2017.

Langseth, Ph. D, Petter, 1999, "Prevention: An Effective Tool to Reduce Corruption", United Nation Office For Drug Control And Crime Prevention (UN-ODCCP), "Global Programme Against Corruption Conforences", Viena.

\section{Internet:}

Harian Terbit, 2015, Kerugian Negara Akibat Korupsi Rp. 31,077 Triliun", available from: URL: http://nasional. harianterbit.com/nasional /2016/02/24/57464/44/25/ICWTahun-2015-Kerugian-NegaraAkibat-Korupsi-Rp31077Triliun, diakses pada tanggal 10 Pebruari 2017.

Hukum online, 2016, "Modus Korupsi Pengadaan, Sebelum dan Sesudah Perpres 54/2010" available from: URL: http:// www.hukumonline.com/berita/ baca/lt57723197ac42e/moduskorupsi-pengadaan--sebelumdan-sesudah-perpres-54-2010, diakses pada tanggal 10 Pebruari 2017.

Okezone.com, 2015, "Beban KPK Semakin Berat, Kejaksaan Harus 
Pro Aktif", available from:

URL: http://news.okezone.com/ $\operatorname{read} / 2015 / 337 / 1249665 /$ bebankpk-semakin-berat-kejaksaanharus-pro-aktif, diakses pada tanggal 10 Pebruari 2017.

Solo Pos, "Sepanjang 2015, Polri Baru Selesaikan 46,5\% Kasus Korupsi”, $\mathrm{S}$ available from: URL: http://m.solopos. com/2015/12/29/kinerja-polrisepanjang-2015-polri-baruselesaikan-465-kasus-korupsi675620 , diakses pada tanggal 10 Pebruari 2017.

Bappenas, 2015, "Laporan Terkait FGD Aksi PPK 2015 Sektor Pengadaan Barang dan Jasa", available from: URL: http:// dapp.bappenas.go.id/up;oad/ file_article/document $/ \% 28 \mathrm{fgd}$ penyusunan-aksi-pencegahandan-pemberantasan-korupsitahun-2015-sektor-pengadaanbarang-dan-jasa $\% 29-F G D \% 20$ Terkait\%20Aksi\%20PPK\%20S ektor $\% 20$ Pengadaan $\% 20$ Baran g\%20dan\%20Jasa-pdf, diakses pada tanggal 10 Pebruari 2017.

\section{Laporan / Hasil Penelitian:}

Komisi Pemberantasan Korupsi,

"Laporan Tahunan 2015-

Menolak Surut”, Jakarta, 2016.

Laporan Singkat Rapat Kerja Komisi

III DPR RI Dengan Jaksa Agung Republik Indonesia, 2016, Masa Sidang V, Senin 13 Juni 2016, Ruang Rapat Komisi IIIDPR RI, Jakarta. 